\title{
O Processo Histórico da Participação da Mulher no Contexto Político Brasileiro
}

\author{
Maria Inês do Rosário Brito ${ }^{1}$ \\ Jaqueline José Silva Oliveira ${ }^{2}$
}

RESUMO: O presente recorte demonstra a ineficácia da Lei n. 9.504/09, a qual prevê a reserva de gênero na lista eleitoral de cada partido político, sendo um percentual de $30 \%$ para ambos os sexos. Após estudo histórico da participação da mulher no meio social, e de um minucioso levantamento estatístico do resultado eleitoral do período de 1994 até 2010, conclui-se que aumentaram significamente o número de candidatas, mas não houve o mesmo impacto no número de deputadas federais eleitas. Assim, com o direcionamento feito neste trabalho, espera-se despertar a sociedade e o mundo acadêmico para pesquisa verticalizada na busca do conhecimento sobre Lei Eleitoral em relação à questão de gênero.

Palavras-chaves: Cotas de Gênero, Lei Eleitoral, Participação da Mulher no Processo Eleitoral

\footnotetext{
${ }^{1}$ Possui graduação em Direito pela Faculdade de Ciências e Educação de Rubiataba. Vice-prefeita de Ceres, eleita, em 2012, prefeita do citado Município.

'Jaqueline José Silva Oliveira: Mestre em Direito, Relações internacionais e Desenvolvimento (PUC-GO) aluna especial no doutorado em Direito Ambiental Internacional (Universidade Católica de Santos), graduada em Direito e Letras habililtação Português/Inglês. Professora da Facer- Faculdades.

E-mails: jaquelineprofessora@hotmail.com
} 


\section{Introdução}

A ausência da mulher na vida pública, e, principalmente, na política, tem sido objeto de muitos estudos e pesquisas. O gênero feminino, por dominar o segredo da vida, através da maternidade, era cultuado pela sociedade como divindade. Todavia, com o passar do tempo, torna-se excluído socialmente.

Tal exclusão tem origem no fato de que após descobrir a participação na concepção da vida, o homem passou a dominar o mundo, relegando o sexo feminino apenas à procriação. Assim, verifica-se ao longo dos séculos, os desafios em relação a esta temática.

No Brasil, para se consolidar a democracia, ainda é necessário avançar na participação da mulher. A Lei de Cotas tem o objetivo de diminuir essa desigualdade de gênero no mundo da política. O objeto dessa pesquisa está focado na análise da eficácia da Lei de cotas de gênero ${ }^{3}$ da participação das mulheres no processo eleitoral.

Este estudo, de forma diacrônica, busca levantar a forma como a mulher foi tratada pela sociedade e como elas reagiram a isto. Observando-se que, por um longo período, foi reservado ao sexo feminino o cuidado com tudo que era doméstico, família, casa, costura, bordado, cozinha, escola e hospital, enfim, somente atividades em que não tinham exposição pública.

No entanto, elas foram à luta e enfrentaram barreiras sociais, culturais e econômicas, organizaram-se criando o Movimento Feminista no Brasil, fortalecidas por vários Tratados Internacionais. Assim, conquistaram muitos avanços no mundo jurídico e social.

${ }^{3}$ Lei n.9.504/97. Disponível em Disponível em http://www.planalto.gov.br/ccivil_03/leis/L9394.htm. Acesso em 10 de dezembro de 2012. 
Contudo, somente em 1995, depois da Nova Constituição Federal, foi aprovado a primeira Lei de Cotas de Mulheres. Em 1997, efetivamente, a Lei de Cotas de Gênero no Processo Eleitoral Brasileiro.

Para o desenvolvimento deste estudo, utilizou-se a pesquisa bibliográfica e documental, realizando a revisão bibliográfica complementada com dados estatísticos do número de mulheres que participaram da Câmara Federal a partir do ano de 1994 ate 2010. Onde foi oportunizado o contato com muitas pesquisadoras que ao longo de 13 anos sistematizaram informações que contribuem no debate acerca deste tema, e diretamente somaram para a produção deste artigo.

Utilizou-se o método histórico para o levantamento da forma como a mulher foi tratada pela sociedade e sua reação até a criação da Lei de cotas de gênero em 1997, no contexto brasileiro. Ainda, o método estatístico em relação os registros da participação da mulher, ao longo dos anos, na política no brasileira. E por fim, os métodos indutivos e dedutivos objetivando a fundamentação das conclusões deste recorte.

O desenvolvimento deste trabalho está sustentado em duas partes: a primeira trata da luta da mulher pelo voto, no cenário histórico brasileiro, até a Constituição Federal de 1988 e a participação política da mulher após a CF/88. A segunda aborda a Lei de Cotas de Gênero. Seguem-se, posteriormente, as considerações finais.

\section{A Luta da Mulher pelo Voto no Contexto Histórico Brasileiro}

Analisar a situação da mulher na sociedade atual, desconhecendo o contexto histórico cultural, remeteria a um equívoco, pois, pode-se concluir 
que foi dado a elas as oportunidades, porém, tem-se certeza da existência de grandes entraves na conquista de cada espaço ocupado por elas.

Em 2003, Célia Regina Jardim Pinto, discorre em sua obra "Uma história do feminismo no Brasil" a partir da atuação de algumas militantes e de organizações que foram decisivas para o movimento feminista no Brasil. Confirma isto analisando a situação social a partir de meados do século XVIII que desde a Revolução Francesa era grave, e com isso surgiram os movimentos para que houvesse uma maior participação política para o povo. Até aqui o único lugar em que as mulheres tinham algum tipo de reconhecimento era como esposas e donas de casa. Estes movimentos refletiam somente a homens (PINTO, 2003, p.13).

Com o movimento sufragista se espalhando pela Europa na segunda metade do século XIX, os direitos femininos começaram a ser reivindicados separados das outras classes. Tiveram que se organizar isoladamente formando um movimento de sufrágio feminino (PINTO, 2003, p.13).

As mulheres eram um grupo de pessoas que, desde a Antiga Grécia, foram impedidas de participar de qualquer decisão política. O primeiro país que garantiu o sufrágio feminino, isto é, o direito das mulheres votarem e ser votadas, foi a Nova Zelândia, em 1893, fruto de movimento liderado por Kate Sheppard. Enquanto que no Brasil, o sufrágio feminino foi garantido quase 40 anos depois.

Em 24 de fevereiro de 1932, quando o presidente Getúlio Vargas assinou o decreto n. 21.076, o qual disciplinava que era eleitor, maior de 21 anos, sem distinção de sexo, alistado na forma do código. (PINTO, 2003, p.28)

No entanto, esse ganho só foi concedido à população feminina depois de grandes lutas, greves, movimentos muitas vezes ditos "bem comportado" ( PINTO, 2003, p.10), por mulheres como Bertha Lutz, a qual será referida mais adiante; ou "malcomportado"( PINTO, 2003, p.10), por 
um grupo de mulheres radicalistas, principalmente, quando se tratava da dominação do homem.

Algumas dessas manifestações foram, em sua grande maioria, organizadas. No entanto, ocorreram outras manifestações isoladas de mulheres que se revoltavam devido às condições em que viviam na época.

Mulheres de personalidade forte, associadas quase sempre a sua intelectualidade, as quais rompiam com suas posições, e se colocavam no mundo público em defesa de seus próprios direitos e dos direitos da sociedade, direitos de cidadania. (PINTO,2003, p. 14 -15):

A luta pela inclusão não se apresentava como alteração das relações de gênero, mas como um suplemento para o bom andamento da sociedade, ou seja, sem mexer com a posição do homem, as mulheres lutavam para ser incluídas como cidadãs.

Nessa época, já sugiram, também, mulheres anarquistas, sendo intelectuais e trabalhadoras por sinal, que, posteriormente, organizaram-se no "Partido Comunista" ( PINTO,2003,p.33).

Tinha manifestações mais radicais, como a exploração do trabalho. Militavam em movimentos de esquerda e incorporavam realmente a defesa da liberdade feminina. E que tiveram um importante papel no processo de emancipação de mulher. Pinto (2003, p.33) continua sua análise pelo século XIX, e afirma que a questão pelo direito ao voto às mulheres, na Constituição de 1891 foi desconsiderada ao estabelecer eleitores cidadãos, maiores de 21 anos que se alistarem na forma da lei.

Nesse sentido, para época, era tão grave o fato de as mulheres não votar. No entanto, segundo o senso comum da época o "cidadão" no masculino não se referia os homens, sendo estes homens e mulheres, mas somente o sexo masculino poderia votar. Daí, a Constituição acabava por excluí-las do direito ao voto, mas não sendo muito claro, esse artigo levou 
muitas mulheres a requererem alistamento ao longo de mais de 40 anos em que vigorou a Constituição (PINTO, 2003, p.16).

\subsection{O Primeiro Partido Político e a Federação Brasileira para o Progresso Feminino}

Como o voto feminino não tinha sido aprovado, um grupo de mulheres em 1910 criaram o Partido Republicano Feminino, (PINTO, 2003, p.18) o que demonstra certa contradição, em razão de ele apontar a existência de um incipiente movimento de construção de espaços públicos na sociedade brasileira.

Nesse caso, por parte de pessoas que estavam completamente excluídas do campo da política e das atividades públicas. Tal atitude deixava bastante claro que a intenção era mesmo essa, tornarem-se representantes dos interesses das mulheres na esfera política. Assim, pretendiam defender não somente o direito ao voto como a emancipação e independência.

Constata Pinto (2003, p. 18) que:

Como a mentalidade feminina já começa a se ampliar em relação aos direitos pelo qual lutam, não mais simplesmente melhorias de trabalho, menor carga horária, ou tempo de descanso para atividades como estudar, ou ocuparem outros espaços além das suas próprias cozinhas. Essas mulheres extrapolando a questão dos direitos cidadãos propunham o fim da exploração sexual, adiantando 50 anos a luta das feministas da segunda metade do século $X X$. 
O Partido Republicano então desapareceu e depois de um longo período de estudos em Paris, Bertha Maria Julia Lutz ${ }^{4}$, uma das figuras pioneiras do feminismo no Brasil volta, em 1922, organiza a Federação Brasileira para o Progresso Feminino (FBPF); de fato a mais conhecida e importante organização em defesa dos direitos negados pelo estado brasileiro à mulher. Tendo o Rio de Janeiro como o principal local de irradiação do movimento, houve proliferação de suas ideias em outros locais (PINTO, 2003, p.21).

Dentre as mulheres efetivas desse movimento, Bertha foi a principal, e desde de Paris teve vivência com as sufragistas, portanto, Bertha tinha condições excepcionais e fundamentais para ser uma liderança na época, além das condições econômicas, culturais dos pais, era uma cientista no serviço público. Escreveu em jornais, viajou e, portanto, desde o início de sua militância esteve influenciada pelas ideias feministas do hemisfério norte (PINTO, 2003, p.22).

Fortemente aliado a Bertha, o senador e depois governador do estado do Rio Grande do Norte, Juvenal Lamartine foi, virtualmente, o representante dos interesses da federação, sendo, até por pressão da mesma, favorável na Comissão de Constituição e Justiça em 1927 ao projeto que legalizava o voto das mulheres (PINTO, 2003, p.24).

Infelizmente, o projeto não foi aprovado. Os movimentos feministas não se restringiam a FBPF, ocorreram sucessivas tentativas de mulheres de se alistarem como eleitoras e até mesmo candidatas. Como Elvira Komel que

\footnotetext{
4- Bertha Maria Julia Lutz nasceu em São Paulo, 2 de agosto de 1894 foi uma das figuras pioneiras do feminismo no Brasil. O pai, Adolfo Lutz, era oriundo de uma família suíça, e a mãe, inglesa. Era zoóloga de profissão. Estudou ciências naturais em Paris, na Sorbonne, com especialização em anfíbios anuros. Depois de tomar contacto com os movimentos feministas da Europa e dos Estados Unidos da América, Berta criou as bases do feminismo no Brasil. Foi a fundadora da Federação Brasileira pelo Progresso Feminino (FBPF), em 1922, após ter representado o Brasil na assembléia geral da Liga das Mulheres Eleitoras, realizada nos Estados Unidos, onde foi eleita vice-presidente da Sociedade Pan-Americana. Foi eleita suplente para deputado federal em 1934, após fracassar em duas eleições. Em 1936 assumiu o mandato. As principais bandeiras de luta eram mudanças na legislação trabalhista com relação ao trabalho feminino e infantil, e até mesmo a igualdade salarial. Em 1937, com o golpe do Estado Novo, perdeu o mandato.
} 
se tornou a primeira mulher mineira eleitora em 1928 (PINTO, 2003, p.26) e Júlia Alves Barbosa, do Rio Grande do Norte, em 1927, que defendeu seus direitos em audiência sob a alegação de ter qualificação de maioridade, solteira, independente financeiramente, portanto, pronta a exercer sua cidadania (PINTO, 2003, p.28).

Em 1939, a FBPF não desanimando tenta, sem sucesso eleger Bertha Lutz para a Constituinte de 1934 e, em 1936, Bertha que ficava como suplente na eleição, assume a cadeira de um deputado que havia morrido (PINTO, 2003, p.28). Estas mulheres não foram simplesmente excepcionais, mas tiveram a coragem de desafiar seus limites políticos e deram um grande salto, não diminuindo suas atividades com pequenas falhas, mas sendo ainda mais animadas a dar continuidade a uma luta de anos, de transformar a organização nacional.

Porém, em um determinado momento em retrocesso na caminhada, 0 golpe de 1937 calou toda a movimentação: "a FBPF foi quase totalmente extinta, e perdeu completamente seu espaço; mesmo depois da redemocratização em 1945, não teve mais expressão no cenário brasileiro" (PINTO, 2003, p.28). Os desafios continuaram e o Sistema de Governo, Anarquismo, incorporava a mulher ao espaço público como companheira revolucionária.

Por outro lado, tinha dificuldade em aceitar sua dominação como um problema diferente ao domínio de classe. Naquele momento, as manifestações de operárias e intelectuais de esquerda sobre a condição da mulher mostraram que a questão de gênero era simplesmente uma organização das desigualdades presentes nas relações de trabalho (PINTO, 2003, p.35).

Nessa perspectiva, a situação das mulheres era vista com outros olhos. "Ser mulher era lutar pelo reconhecimento da especificidade da opressão", ou seja, os oprimidos não são oprimidos das mesma forma, mas existem várias formas de opressão"(PINTO, 2003,p.35). 


\title{
1.3. A grande descoberta
}

No século $X X$, a situação começa esquentar um pouco mais, as mulheres que antes lutavam somente por direitos cidadãos, pela inclusão, falavam de dominação dos homens sobre as mulheres. (PINTO, 2003, p.36).

Identificam na sua exclusão razões para os homens terem mais poder (PINTO, 2003, p.36). Assim como para Maria Moura, umas das mais importantes militantes do início do século XX, nascida em 1887, em Minas Gerais, de família pobre, professora e autora de muitos livros, afirmava: "O homem aparecia como o opressor identificado no capitalista, no patrão que explorava as mulheres" (PINTO, 2003, p.37).

Quando se trata de autonomia e conquista, a liberdade da mulher professora Tatau Godinho5, esclarece em 2004, no livro "A mulher brasileira nos espaços públicos e privados", como elas querem essa liberdade:

\begin{abstract}
Para as mulheres, o destaque para a liberdade e a igualdade sugere com freqüência a relação com liberdades individuais no campo da vida pessoal e familiar. Ser respeitada e ter seus direitos respeitados é a expressão mais freqüente relacionada a direitos individuais. Também mencionada genericamente como um direito, a liberdade é associada à liberdade de poder trabalhar, de poder sair de casa, de sair/casar ou namorar com quem quiser, ser independente, e ao direito de ir e vir para onde quiser. (GODINHO, 2004, p. 154)
\end{abstract}

Nessa época, a militante Maria Moura defendia o estudo das causas sociais da condição da mulher, apontando o capitalismo como o grande responsável. Era uma postura, diferente de Bertha Lutz, que lutava por grandes transformações e repelia a luta por direitos civis (PINTO, 2003,

\footnotetext{
${ }^{5}$-Tatau Godinho, mestra em sociologia pela Pontifícia Universidade Católica de São Paulo, Coordenadora Geral da Coordenadoria da Mulher do Município de São Paulo e integrante da Secretaria Nacional de Mulheres do Partido dos Trabalhadores,
} 
p.37). Ou seja, as mulheres também teriam seus direitos de participar, e seriam livres. Foi considerado um feminismo "malcriado" (PINTO, 2003, p.38) fazia enfrentamento e era reforçado pelos anarquistas radicais, que ainda "traziam para discussão um mundo de trabalho, onde a mulher era oprimida, muito distante das preocupações das feministas de elites" (PINTO, 2003, p.38).

Nas décadas de 1960 e 1970, o clima ainda estava quente, tanto nos Estados Unidos quanto na Europa, o governo era ditatorial, e mesmo com toda uma cultura influenciando, os movimentos socialistas surgiam em vários cantos do mundo.

Mas a situação da mulher continuava tendo como espaço os seus lares. No entanto, esse sentimento de feminismo, mesmo quando essa palavra ainda não podia ser dita com tranqüilidade, já havia aflorado e animado uma boa parte de classe feminina. Trabalhadoras, operárias, donas de casa, mulheres que com muito custo e influência, conseguiram espaço em locais privados e até públicos, não deixaram a repressão do governo, principalmente, de Médici, desanimá-las (PINTO, 2003, p.43).

Conforme descreve Godinho (2004, p.151):

As décadas de 1970 e 1980 representaram um período também de crescimento maciço na participação política das mulheres. A presença em movimentos sociais ativos, respondendo às novas demandas surgidas em particular nas grandes concentrações urbanas, introduziu novas formas de sociabilidade e oportunidades para as mulheres fora do âmbito familiar. Nos movimentos populares urbanos e presença marcante das mulheres é significativamente maior do que o movimento sindical e nos espaços da política partidária e parlamentar. Mas mesmo nas entidades sindicais e partidárias, mais marcadamente masculinas, é grande o crescimento de sua participação. A partir do final dos anos 1980 também ganhou fôlego a presença das mulheres nos movimentos rurais. 
Com o golpe militar de 1964, esses movimentos sociais e quaisquer outras formas de manifestações, principalmente, quando se trata de direitos políticos, eram alvos de cassações, prisões, censuras, desaparecimentos inesperados e, até tortura.

Logo após, final da década de 1970 e inicio de 1980, entretanto, o movimento de mulheres se dividem, em dois Partidos Políticos, mas, fortalecem seus movimentos por direitos iguais agora com a presença do PT (Partido dos Trabalhadores) e do PMDB (Partido do Movimento Democrático Brasileiro) (PINTO, 2003, p.45).

Esses avanços retratam claramente, nas décadas seguintes, que são consideradas pelas pesquisadoras como uma luz e estímulo para os movimentos. Porém, existiam divisões que às vezes colocava em questão a fragilidade do grupo de mulheres, (PINTO, 2003, p.55), uma vez que poderia diminuir a força do movimento feminista. Movimento este que segundo Pinto (2003, p. 46) deveria ser entendido como:

\footnotetext{
Um movimento que luta por autonomia em um espaço profundamente marcado pelo político; defende a especificidade da condição dominada da mulher, numa sociedade em que a condição de dominado é comum a grandes parcelas da população; no qual há diferentes mulheres enfrentando uma gama de problemas diferenciados.
}

Observa-se que em 1975, com o governo de Geisel a história do feminismo teve um marco. A decisão da ONU (Organização das Nações Unidas) de definir este ano como o Ano Internacional da Mulher e ainda um evento com o título: O papel e o comportamento da mulher na realidade brasileira, criando o Centro de Desenvolvimento da Mulher Brasileira. (PINTO, 2003, p.56). 
A partir daí as mudanças começam a caminhar mais rapidamente, pesquisas começaram a surgir. O papel da mulher passava a ser mais questionado tanto entre as próprias mulheres como entre outras classes.

Cria-se, também, o Dia Internacional da Mulher (8 de março), comemorações em vários Estados e Municípios. As entidades de mulheres tiveram participação decisiva, já que lutava tanto a favor do feminismo como da democracia.

Dessa forma, com a anistia e a reforma partidária, o Brasil agora estava rumo à democratização e devia, sem sombra de dúvida muito, aos movimentos feministas reforçados, principalmente, com o Centro de Desenvolvimento da Mulher Brasileira (PINTO, 2003,p.64).

"Essas mulheres havia descoberto seus direitos e, mais do que isso, talvez a mais desafiadora das descobertas, havia descobertos seus corpos, com suas mazelas e seus prazeres" (PINTO, 2003, p.65).

Com a redemocratização, ou seja, o fim de tantas repressões, o país enfrentava uma reforma partidária e a anistia aos presos e exilados políticos. A sociedade não era mais vigiada com tanta repressão e, assim, gradualmente foi-se democratizando.

A mulher já conquistava cargos através de eleições e uma maior participação política. Fruto de lutas, repressões, tensões, insistências e resistências no campo político as quais só ameaçavam a unidade do movimento feminista. Uma política que transformou o cotidiano das classes sociais e das mulheres. (PINTO, 2003).

Como afirma Soares (1988, p. 40) "assim, as mulheres pobres, a partir da ação política para melhorar suas vidas e a de seus familiares, se redefiniam para si mesmas como legítimas atrizes públicas e modificavam as normas tradicionais que limitam a mulher ao âmbito privado do lar". 


\subsection{O impacto da constituição de 1988 no movimento feminista}

Em 1988, para demonstrar as mudanças que ocorriam no país que saía de um regime autoritário para um governo constitucional democrático, foi elaborada a Constituição Federal, a fim de organizar, e fortalecer a sociedade.

No entanto, como coloca Pinto (2003, p.73), é surpreendente quando se trata dos cargos eleitorais ocupados na Câmara dos Deputados, por exemplo, o fato da região sudeste, a mais urbanizada e desenvolvida do país e onde, sem dúvida, o movimento feminista era mais forte e tinha mais visibilidade, ter elegido um número tão pequeno de mulheres. Apesar de que só o fato de se fazer presente na política de um país que passou por tanta repressão, já era mérito.

Como coloca, ainda, a autora, a trajetória do movimento feminista é surpreendente. Superando diversas extrações partidárias, denominando-se "bancada feminina" (PINTO, 2003, p.74), além disso, apresentava emendas reivindicando todas aquelas questões envolvendo assuntos principais como o aborto, sexualidade, violência e posição da mulher na família, que durante tanto tempo foi questionado por grupos de mulheres (PINTO, 2003, p.74).

Sabemos que, embora a realidade tenha se modificado bastante, ser mulher com atuação política ainda é atividade vista com preconceito. Afinal, nossos dicionários ainda registram prostituta como sinônimo de mulher pública, enquanto homem público é sinônimo de autoridade e político. O parlamento e o mundo da política em geral - o Poder Executivo, o Judiciário, os partidos políticos e os sindicatos - são espaços hostis para as mulheres. (BORBA, 1998, p.156).

Infelizmente ,a sociedade ainda tinha, olhares preconceituosos quanto à participação da mulher na política, como se fosse a disponibilidade para 
função pública, onde ela se divide entre sua família e a sociedade, sinônimo de desonra.

Nesse contexto, foi elaborada a "Carta das Mulheres", documento este proposto pelo Conselho Nacional dos Direitos da Mulher - CNDM, uma vez que para as deputadas mulheres a qual fizeram a carta, a Constituição sem mulher fica pela metade, ou seja, atender os direitos da mulher é questão de democracia. Relata Pinto (2003, p.74), detalhando ainda todos os pontos os quais o documento defendia, como a criação do Sistema Único de Saúde, autonomia sindical, ensino público e gratuito em todos os níveis, entre outros.

Além, disso, a autora cita as emendas em relação aos direitos da mulher, ao trabalho, à saúde, à sociedade conjugal e a questão da violência. Solicitando a criação de delegacias especializadas no atendimento a mulher, sobre o aborto em casos, por exemplo, de estupro. Enfim, as mulheres queriam o direito de ser reconhecidas pela sociedade $\mathrm{e}$ decidirem por si mesmas (PINTO, 2003, p.75).

Pinto (2003) fecha essa questão colocando o rápido declínio do CNDM, uma vez que nem todas suas propostas foram atendidas pela Câmara, até porque não tinha uma bancada muito forte para se sustentar e pressionar o governo. No entanto, a autora afirma que tal mobilização, expressa nas emendas populares à Constituinte, possibilitou o movimento feminista ser protagonista em um cenário muito particular e promissor, no caso do Brasil (PINTO, 2003, p.79).

\subsection{Participação política da mulher após a Constituição de 1998}

Quando se trata do espaço político alcançado pela mulher depois de tantos movimentos e organizações, fica claro, avanço originado de tantas discussões. Como exemplo disso, a expansão das ONGs, um tipo de organização vinda de movimentos sociais. Não se pode falar que tais organizações não foram importantes para os movimentos feministas. 
Essas organizações se preocuparam com as mulheres rurais, mulheres portadoras de HIV, mulheres parlamentares, mulheres negras, mulheres prostitutas, entre outros grupos, ou seja, um feminismo com segmentação das lutas.

Dessa forma, enfatiza-se que após a virada do século, continuaram a existir uma série de manifestações de mulheres, em sindicatos, em partidos políticos lutando pelos direitos das mulheres Pinto (2003).

Por intermédio de ONGs o feminismo existiu e se manifestou no Brasil. Um exemplo claro, colocado por Pinto (2003) é o CFEMEA (Centro Feminista de Estudos e Assessorias), criado em 1989, fazendo um trabalho junto ao Poder Legislativo, atuando de forma comprometida com o movimento de mulheres.

A atuação dessa e outras Organizações não Governamentais- ONGs conseguiram ampliar os espaços da mulher na vida pública, não pretendendo suas participações na política institucional. Pinto (2004, p.106) fecha muito bem toda a caminhada do movimento feminista:

\begin{abstract}
A gama de organizações que hoje atuam no Brasil e que variam muito quanto a suas clientelas, seus propósitos, sua capacidade de intervenção. Algumas são mobilizadas, outras prestam assessoria especializada, outras ainda são prestadoras de serviços. Atuam tanto junto a sociedade quanto junto ao Estado, algumas delas com assento em conselhos, outras sendo interlocutoras de ministros e parlamentares. Essa é a fase por que passa o feminismo no Brasil, mas a sua trajetória não acaba aqui. Como muitas outras lutas populares e identitárias no Brasil, o feminismo tem uma longa história pela frente.
\end{abstract}

Reforça-se a questão, de que muito ainda tem que ser feito. No entanto, todos os movimentos que marcaram o feminismo, ou que de alguma forma contribuíram para uma maior participação da mulher nas decisões políticas é certamente, o motivo pelo qual as mulheres de hoje têm "tanto" poder nas mãos. Essa ideia de que a mulher tinha que romper 
com a construção histórico-cultural da obrigação de ser somente dona de casa, além de mãe e esposa. Garcia (1998, p.186) afirma que:

\begin{abstract}
Devemos considerar que o principal desafio é romper com a idéia e o discurso do destino biológico da mulher, que impõe papéis e a condiciona histórica e culturalmente as funções relacionadas à maternidade e à família. A partir desta consideração e constatação, assumir o desafio de agir no sentido de alterar as relações de desigualdade entre os gêneros. Esse ponto de partida é importante para não se reforçar as atribuições tradicionais da mulher como única saída, ou passar por cima da posição em que está a maioria das mulheres na sociedade.
\end{abstract}

Essa mudança trouxe uma revolução social, é o começo de uma nova história, agora com a participação direta da mulher nos espaços de poder. É valido ressaltar a participação do movimento sindical na emancipação do sexo feminino. Conforme relata Delgado (1998), houve uma grande parceria entre o movimento feminista e a CUT - Central Única de Trabalhadores. Organização criada em 1983 se tornando bastante representativa no Brasil.

Ocorreram grandes contribuições partindo dessa parceria, Influenciando para que ocorram mudanças na cultura que vigora no movimento sindical, de valores e compreensão das relações sociais. Além, da cota mínima de participação feminina nas direções do movimento ter sido base para a primeira lei de cotas no processo eleitoral (DELGADO, 1998, p.209).

Delgado (1998) afirma que em um debate no ano de 1991, no II Encontro Nacional sobre a Mulher Trabalhadora, que se prolongou até a VI Plenária Nacional da CUT em 1993, aprovou a adoção de um mínimo de $30 \%$ e um máximo de $70 \%$ de cada sexo nas instâncias de direção da entidade. Em 1994, elegeu-se a primeira Executiva Nacional da CUT com esta composição nova (DELGADO, 1998, p.217).

Delgado (1998, p. 217) ainda afirma: 
A discussão da cota foi sem dúvida, estimulada pela experiência do Partido dos Trabalhadores, cujo $1^{\circ}$ Congresso, em 1991, havia aprovado a adoção dessa medida, depois de um pioneiro debate, igualmente significativo, introduzido pela Secretaria Nacional de Mulheres.

A partir da experiência do movimento sindical, e do Partido dos Trabalhadores, as mulheres, nesse momento a bancada feminina no Congresso Nacional, titulada "Bancada do Batom", movimentaram-se e conseguiram criar em 1995 a primeira lei de cotas de gênero. Porém, até então, eram na verdade, cotas de mulheres, que depois de aprovadas foram aperfeiçoada até chegar à Lei n.9.504/97 que até hoje está em execução no País. A qual será analisada a seguir.

\section{A Lei de Cotas de Gênero}

\subsection{Motivação dos legisladores brasileiros na criação da lei de cotas de gênero no processo eleitoral}

O movimento sufragista ou 0 feminista chega ao século $X X$ comemorando a inserção da mulher no mercado de trabalho, na formação acadêmica, no direito ao voto e mudanças no direito de família, enfim, muitas conquistas significativas.

Destaca-se ainda, a participação efetiva do chamado "sexo frágil" nas grandes revoluções como a Francesa, Americana, Industrial, inclusive a Abolição da Escravatura.

O Brasil no final do século XX, passava por uma redemocratização, entre outras ações, era necessário dar respostas aos movimentos 
nacionais e internacionais de luta por Direitos da Mulher. Reverter tal desigualdade, ainda existente, era a tarefa da sociedade, confirmando que, neste momento, as demandas não eram mais individuais e sim coletivas, pois a própria mulher já havia percebido que isolada não chegaria a alcançar seus objetivos.

Portanto, torna-se imperiosa a manifestação dos Estados através de ações objetivando a ampliação da participação das mulheres nos espaços de decisão e de poder, no âmbito da Câmara Federal, do Senado, das assembleias estaduais e municipais. Além do poder executivo, prefeitas, governadoras e até Presidenta da República. Garcia, discorre sobre o exercício de sua cidadania, como uma ação coletiva.

\begin{abstract}
A cidadania para as mulheres não significa a simples extensão dos direitos já conquistados pelos homens, acrescidos daqueles referentes à condição feminina em função da procriação. Pressupõe trabalharmos o conceito de cidadania como a construção de uma condição coletiva, generalizada e inclusiva, ou seja, construir as condições de liberdade e igualdade para todos" (Partidos dos Trabalhadores, 1994). (GARCIA, 1998, p.178)
\end{abstract}

O quadro abaixo comprova que a presença feminina na atividade pública já era marcante, parece contraditório, porém, essa atividade era de apoio ao homem. As estatísticas mostram a pequena presença dela nos cargos eletivos, como será aprofundado a seguir.

Outra analise importante é a atuação da mulher nas atividades domésticas, seja na esfera pessoal ou familiar, além da educação e saúde que foi historicamente delegado a elas como complemento das tarefas domésticas.

Com isso, destacam-se os espaços sociais "permitidos" culturalmente para a atuação da mulher.

Tabela 1 - População ocupada nos setores de atividades segundo o sexo (\%) 


\begin{tabular}{|c|c|c|c|c|}
\hline \multirow{2}{*}{$\begin{array}{l}\text { Setor de } \\
\text { Atividade }\end{array}$} & \multicolumn{2}{|c|}{1985} & \multicolumn{2}{|c|}{1995} \\
\hline & Homem & Mulher & Homem & Mulher \\
\hline Agropecuária & 79,94 & 20,06 & 75,91 & 24,09 \\
\hline $\begin{array}{l}\text { Extração } \\
\text { vegetal/mineral }\end{array}$ & 66,77 & 33,23 & 64,72 & 35,28 \\
\hline Indústria geral & 73,55 & 26,45 & 72,91 & 27,09 \\
\hline Construção civil & 98,18 & 1,82 & 98,03 & 1,97 \\
\hline $\begin{array}{l}\text { Serviços } \\
\text { industriais de } \\
\text { utilidade } \\
\text { pública }\end{array}$ & 85,69 & 14,31 & 78,49 & 21,51 \\
\hline Comércio & 68,21 & 31,79 & 61,57 & 38,43 \\
\hline Transportes & 95,14 & 4,86 & 94,62 & 5,38 \\
\hline Comunicação & 70,94 & 29,06 & 68,62 & 31,38 \\
\hline $\begin{array}{l}\text { Instituições } \\
\text { financeiras }\end{array}$ & 65,40 & 34,60 & 58,74 & 41,26 \\
\hline $\begin{array}{l}\text { Administração } \\
\text { pública }\end{array}$ & 47,22 & 52,78 & 42,57 & 57,43 \\
\hline $\begin{array}{l}\text { Outros serviços } \\
\text { técnicos } \\
\text { profissionais }\end{array}$ & 65,51 & 34,49 & 59,12 & 40,88 \\
\hline
\end{tabular}




\begin{tabular}{|l|l|l|l|l|}
\hline $\begin{array}{l}\text { Outros serviços } \\
\text { prestados as } \\
\text { empresas }\end{array}$ & 72,65 & 27,35 & 73,10 & 26,90 \\
\hline $\begin{array}{l}\text { Outros serviços } \\
\text { de saúde e } \\
\text { ensino }\end{array}$ & 29,75 & 70,25 & 27,63 & 72,37 \\
\hline $\begin{array}{l}\text { Outros serviços } \\
\text { comunitários }\end{array}$ & 50,49 & 49,51 & 44,36 & 55,64 \\
\hline $\begin{array}{l}\text { Outros serviços } \\
\text { de reparação e } \\
\text { conservação }\end{array}$ & 97,90 & 2,10 & 96,10 & 3,90 \\
\hline $\begin{array}{l}\text { Outros serviços } \\
\text { se } \\
\text { hospedagem e } \\
\text { a alimentação }\end{array}$ & 60,58 & 39,42 & 55,14 & 44,86 \\
\hline $\begin{array}{l}\text { Outros serviços } \\
\text { pessoais }\end{array}$ & 14,06 & 85,94 & 14,31 & 85,69 \\
\hline $\begin{array}{l}\text { Outros serviços } \\
\text { sociais }\end{array}$ & 80,96 & 19,04 & 70,93 & 29,07 \\
\hline $\begin{array}{l}\text { Outros serviços } \\
\text { distributivos }\end{array}$ & 72,33 & $63,87,67$ & 93,16 \\
\hline $\begin{array}{l}\text { Outros seriliares } \\
\text { derviço }\end{array}$ & 84,03 & $71,76,19$ \\
\hline
\end{tabular}




\begin{tabular}{|l|l|l|l|l|}
\hline remunerado & & & & \\
\hline $\begin{array}{l}\text { Total da } \\
\text { Economia }\end{array}$ & 66,58 & 33,42 & 62,05 & 37,95 \\
\hline
\end{tabular}

Fonte: IBGE/PNAD, 1985 e 1995 ( In: MELO, 1998, p.59)

\title{
2.1.1. Cidadania e Mulher
}

As atividades exercidas pelas mulheres no que tange aos seus direitos políticos pressupõem também os seus direitos civis, daí é impossível falar da participação nos espaços de poder sem considerar os conceitos trazidos pelo movimento feminista.

Destaca-se a existência da possibilidade de se colocar em pauta, na sociedade brasileira, a questão de gênero debatida até então, por grupos de mulheres e por instituições de esquerda. Os pesquisadores como Ribeiro se refere a esse período coma implantação de um novo conceito de Cidadania.

\begin{abstract}
A partir de meados da década de 1980, com redemocratização do país, o tema cidadania tem sido debatido não apenas como um acesso a direitos, mas como capacidade dos indivíduos de participar na organização do Estado e da sociedade, contribuindo na elaboração de políticas públicas capazes de concretizar os direitos formais. (RIBEIRO,1998, p.190)
\end{abstract}

A construção social iniciada na pós-ditadura chama a sociedade para planejar um novo país, agora democrático com eleições diretas, com novas regras, um processo constituinte que busca responder todos os anseios da comunidade que, por outro lado, continua sua organização, seja em associações, sindicatos ou outra entidade para participar desse momento histórico e contribuir diretamente para a elaboração da nova constituição. 
Qualquer idéia de construção de uma cidadania feminina plena passa por uma discussão do tamanho do Estado. Existem duas possíveis respostas ou soluções para a crise do Estado de bemestar. A primeira seria a melhoria dos serviços prestados pelo Estado, eliminando-se toda ineficiência de sua administração. (MELO, 1998, p. 66)

A partir daí, intensifica-se a ideia de um novo modelo social, que visa um desenvolvimento humano integral, pois não existiria democracia sem respeito às diferenças, seja no aspecto político, social ou econômico. Incluindo os direitos humanos no debate acerca do Desenvolvimento Social almejado pelo Brasil naquele momento:

O conceito de cidadania que o feminismo vai explorar está vinculado ao acesso e à redefinição de direitos: direitos a ter direitos. Identifica a cidadania com o processo de criação de espaços públicos novos e múltiplos, não com a mera ocupação de espaços existentes anteriores à prática dos sujeitos políticos. (SOARES, 2004, p.172.)

Nesse contexto, foi colocado na pauta do dia o conceito de cidadania que se inspira no propósito de um grande mutirão social em que cada indivíduo tem o seu papel no meio social, seja na cobrança de seus direitos como no cumprimento de suas obrigações.

A estrutura estatal, Estados, Municípios e União têm a função de criar as condições para esse novo indivíduo, agora no exercício de sua cidadania, poder usufruir de seus direitos.

As mulheres têm um papel fundamental nesse momento, já com grupos organizados, como foi visto nos capítulos anteriores, elas continuam a exigir seus direitos entre eles, o de ser votada.

Porém, faz-se necessário lembrar que não é somente a oportunidade de militarem em seus partidos políticos e de se inscreverem como candidatas, mas sim ocuparem sua cota nos espaços de poder, considerando que o país estava passando por mudanças, em que se tenta colocar em prática os avanços constitucionais como as previsões do artigo 
5 da $\mathrm{CF} / 88^{\circ}$, que será visto posteriormente. É importante também analisar mais profundamente o que é cidadania.

O conceito liberal de cidadania tem suas bases na Declaração Francesa dos Direitos do Homem e do Cidadão, de 1791. Diz respeito ao 'direito à representação política'e o cidadão é definido como indivíduo nacional titular de direitos eleitorais (votar e ser votado) e do direito de exercer cargos públicos. (PAULILO, 1999, p.1).

A pesquisadora se refere à cidadania em um conceito liberal, como sendo um instrumento de representação política, afirmando que cidadão é quem poderá votar e ser votado, o que leva a seguinte reflexão, será que até agora as mulheres são menos cidadãs? Se forem considerados seus direitos eleitorais que foram cerceados ao longo da história, concluir-se-ão que foram excluídas do exercício de cidadania. Ela continua analisando a relação entre a cidadania e igualdade:

A igualdade não passa pelo econômico, mas pelo político. Há uma valorização do individuo como categoria abstrata, atomizada, desvinculada das condições sócio-econômicas onde se insere. A cidadania é representação política. (PAULILO, 1999, p.2).

Portanto, percebe-se a fragilidade para promoção da igualdade e por conseqüência da cidadania, em função da pouca participação feminina no campo político, pois culturalmente ela cuidou das atividades domésticas conforme Tabela 1 - (População ocupada nos setores de atividades segundo o sexo (\%)). Contudo, era necessário buscar respostas para esse quebra-cabeça, como envolvê-las e estimulá-las ao exercício da cidadania através das candidaturas?

Esse questionamento foi o principal desafio encontrado na busca de se planejar as ações, que viesse a contribuir para reversão da realidade de injustiça social e assegurar a igualdade entre homens e mulheres tanto no âmbito civil quanto político. 


\title{
2.2. Participação da mulher nos espaços de poder no mundo
}

Como a situação de marginalização da mulher é um fenômeno globalizado, as estatísticas demonstram que as dificuldades são as mesmas e só mudam de nacionalidade, incorporando alguns comportamentos culturais do país.

Porém, em regra, as desigualdades sociais que afetam as mães, esposas, filhas e trabalhadoras expressas pela falta de políticas públicas que garantam a "igualdade" de oportunidade de acesso aos seus direitos mínimos. Questão que será aprofundada no próximo tópico, como também, a respeito da dignidade da pessoa humana, a qual será sempre motivo de muita disputa.

\begin{abstract}
A situação de exclusão das mulheres dos espaços públicos pode ser observada durante toda a história da humanidade: a submissão das mulheres de Atenas, as mulheres como objeto de troca nas sociedades tribais, as bruxas e pecadoras queimadas na inquisição durante a Idade Média e as revolucionárias que ficaram e que escreverem as páginas que narraram essa história. É em meio à condição de subordinação patriarcal que o feminismo latino-americano, mesmo que com poucas vozes a princípio, eclodiu através de gritos que ressoaram aos quatros cantos do mundo e desencadearam na região movimentos de reivindicação e conscientização feminina, seja na forma de partidos, nas organizações políticas, em periódicos, nos centros de estudo e organizações nãogovernamentais. (MATOS, et al, 2007, p.5)
\end{abstract}

A realidade da América Latina quanto à presença das mulheres no Parlamento, é analisada e comparada com o resto do mundo, chegando às pesquisadoras a sistematizar estas tabelas que demonstram com clareza os números deste preocupante cenário.

Tabela 2 - Mulheres no Parlamento em países da América Latina e por ordem de colocação entre 179 países

\begin{tabular}{|l|l|l|l|l|}
\hline Países & Últimas & Número & $\%$ de & Colocação \\
\hline
\end{tabular}




\begin{tabular}{|c|c|c|c|c|}
\hline & $\begin{array}{l}\text { eleições } \\
\text { realizadas }\end{array}$ & $\begin{array}{c}\text { de } \\
\text { mulheres } \\
\text { eleitas }\end{array}$ & $\begin{array}{c}\text { mulheres } \\
\text { no } \\
\text { Parlamento }\end{array}$ & $\begin{array}{c}\text { no ranking } \\
\text { internacional }\end{array}$ \\
\hline Cuba & 1998 & 166 & 27,6 & $13^{\circ}$ \\
\hline Argentina & 1999 & 71 & 26,5 & $16^{\circ}$ \\
\hline Costa Rica & 1998 & 11 & 19,3 & $29^{\circ}$ \\
\hline Guiana & 1997 & 12 & 18,5 & $25^{\circ}$ \\
\hline Equador & 1998 & 21 & 17,4 & $30^{\circ}$ \\
\hline México & 1997 & 87 & 17,4 & $30^{\circ}$ \\
\hline El Salvador & 1997 & 14 & 16,7 & $33^{\circ}$ \\
\hline $\begin{array}{l}\text { República } \\
\text { Dominicana }\end{array}$ & 1998 & 24 & 16,1 & $35^{\circ}$ \\
\hline Jamaica & 1997 & 8 & 13,3 & $41^{\circ}$ \\
\hline Guatemala & 1995 & 10 & 12,5 & $44^{\circ}$ \\
\hline Venezuela & 1998 & 25 & 12,1 & $47^{\circ}$ \\
\hline Colômbia & 1998 & 19 & 11,8 & $49^{\circ}$ \\
\hline Bolívia & 1997 & 15 & 11,5 & $51^{\circ}$ \\
\hline $\begin{array}{l}\text { Trinidad y } \\
\text { Tobago }\end{array}$ & 1995 & 4 & 11,1 & $53^{\circ}$ \\
\hline Chile & 1997 & 13 & 18,8 & $55^{\circ}$ \\
\hline
\end{tabular}




\begin{tabular}{|l|l|l|l|l|}
\hline Peru & 1995 & 13 & 10,8 & $55^{\circ}$ \\
\hline Nicarágua & 1996 & 9 & 9,7 & $60^{\circ}$ \\
\hline Panamá & 1999 & 7 & 9,7 & $60^{\circ}$ \\
\hline Honduras & 1997 & 12 & 9,4 & $62^{\circ}$ \\
\hline Uruguai & 1994 & 7 & 7,1 & $79^{\circ}$ \\
\hline Brasil & 1998 & 29 & 5,6 & $89^{\circ}$ \\
\hline Paraguai & 1998 & 2 & 2,5 & $104^{\circ}$ \\
\hline
\end{tabular}

Fonte: IPU (1999) ( In: ARAÚJO, 2001, p.7)

Tabela 3 - Representação feminina no Legislativo em diferentes países ${ }^{6}$

\begin{tabular}{|l|l|l|}
\hline \multicolumn{1}{|c|}{ PAÍS } & DEPUTADAS & SENADORAS \\
\hline Argentina & $27 \%$ & $3 \%$ \\
\hline México & $16 \%$ & $16 \%$ \\
\hline Colômbia & $12 \%$ & $13 \%$ \\
\hline Chile & $11 \%$ & $4 \%$ \\
\hline Uruguai & $10 \%$ & $10 \%$ \\
\hline
\end{tabular}

${ }^{6}$ (Mulher e Política: Do voto feminino à Lei das Cotas: a difícil inserção das mulheres nas democracias representativas, Mary Ferreira / disponível em www.espaçoacademico.com.br/036/37cferreira.htm acesso em 24/03/2010) 


\begin{tabular}{|l|l|l|}
\hline Brasil & $8,2 \%$ & $12 \%$ \\
\hline $\begin{array}{l}\text { Estados } \\
\text { Unidos }\end{array}$ & $14 \%$ & $13 \%$ \\
\hline Canadá & $21 \%$ & $35 \%$ \\
\hline Moçambique & $27 \%$ & - \\
\hline
\end{tabular}

( FERREIRA, 2004, p.01)

Os dados sistematizados nestas pesquisas confirmam o sentimento de consenso mundial de que a participação da mulher nos espaços de decisão no âmbito global é incipiente.

Pior ainda quando analisado a posição do Brasil, que apesar de em 1998 já ser uma democracia e ter uma legislação eleitoral que contemple as cotas, ocupa a $89^{\circ}$, posição com um percentual de $5,6 \%$, perdendo para outras nações chamadas como menos "desenvolvidas" em relação aos direitos sociais, culturais, políticos e econômicos.

Esses dados se mantêm como se percebe na tabela 2 (aproximadamente dez anos depois) apesar do percentual passar para $8,2 \%$ a câmara federal e $12 \%$ no senado, continua com índices sem expressão e mal colocado mundialmente. Por isso, foram fundamentais as mudanças no Plano Jurídico, BORBA aborda esse aspecto:

Praticamente todas as confrências internacionais que abordaram a situação da mulher, manifestaram em suas resoluções a necessidade de decisão, em situação de igualdade com os homens. A Plataforma de Ação aprovada na IV Conferência Mundial sobre a Mulher dedicou um capitulo exclusivo a questão, afirmando que "a igualdade de participação das mulheres nas decisões políticas é indispensável para reforçar e aprofundar a democracia, aumentar a transparência dos processos políticos". (BORBA, 1998, p.169) 


\title{
2.3. Avanços no Plano Jurídico no Brasil
}

Para se analisar os avanços jurídicos implementados na questão de gênero nos últimos anos no país, deve-se considerar as lutas travadas pelos movimentos nacionais e internacionais. É mister destacar como já foi analisado, que os legisladores foram "obrigados" a adequar as normas jurídicas a realidade, que emergiu a partir das disputas políticas e sociais vividas no final do século $X X$.

Outro aspecto é a analise do empobrecimento e marginalização das mulheres diante do modelo econômica neoliberal, em que o Estado brasileiro, entre outros, é omisso e permite que as regras sejam executas pelo próprio mercado, o que representa manutenção do modelo de exclusão social feminino.

\begin{abstract}
[...] no final do século $X X$, transcorridos dois anos da realização da ultima Conferência Internacional da Mulher (Pequim, setembro de 1995) promovida pela ONU, que como as anteriores, declarou a igualdade na lei entre homens e mulheres, assiste-se a destruição dos direitos sociais e não se leva em consideração o desigual cotidiano feminino.que tipo de sociedade as políticas neoliberais tem deixado em seu rastro? Uma sociedade heterogênea, marcada por profundas desigualdades - classe, gênero, raça - que foram exacerbadas por essas políticas. Os excluídos estão condenados a marginalidade e aí reside o grande problema para as massas femininas, que formam uma grande parcela dos pobres do mundo. (MELO, 1998, p.66)
\end{abstract}

Neste contexto de grandes desigualdades sociais e falta de políticas de gênero, classe e raça, destaca-se a necessidade de abolir determinadas normas, em detrimento a criação de novas. "A luta das mulheres brasileiras nestas últimas décadas possibilitou eliminar da legislação nacional um conjunto de normas e leis que restringiam o acesso das mulheres a plena cidadania". (MELO, 1998, p.67). 


\title{
2.3.1. Tratados Internacionais
}

A sociedade mundial preocupada com essa realidade cria a Organização das Nações Unidas - ONU e começa a produzir documentos que visa à cooperação internacional para a busca de melhores condições de vida, seja, no campo social, econômico, cultural, ambiental e político, justificando-se o debate acerca da questão de gênero a partir dos direitos humanos. Que é definida por Benevides ( como aquele comum a todos e todas independente de características pessoais e de grupo que preserve em primeiro lugar a vida, a dignidade da pessoa humana e dos direitos civis:

\begin{abstract}
Direitos humanos são aqueles direitos comuns a todos os seres humanos, sem distinção de raça, etnia, nacionalidade, sexo, orientação política e julgamento moral, e que tem como pressuposto óbvio o direito a vida. Decorrem do reconhecimento da dignidade intríseca a todo ser humano e diferem dos direitos do cidadão, embora estes estejam, em grande parte, ai incluídos, porque os direitos humanos extrapolam as condições legais e as fronteiras, as quais definem a cidadania e a nacionalidade. (BENEVIDES, 1998, p.138).
\end{abstract}

Portanto, a grande tarefa colocada naquele momento era diminuir as desigualdades existentes no mundo. Pensar em valorizar o ser humano se faz necessário planejar ações que garantam as condições mínimas de vida digna. Como já discorrido anteriormente, esse aspecto está diretamente relacionado com os direitos da mulher apesar, da sua superioridade, vale destacar a influencia desse recorte na conquista da cidadania das mulheres. A tão sonhada igualdade entre os sexos começa a ser citada como algo possível para o processo Democrático Brasileiro.

A igualdade é sempre uma dimensão social, não individual. Ao contrário da liberdade, ela ocorre sempre dentro de um grupo social, ou entre grupos sociais e não entre indivíduos isoladamente considerados. Podemos identificar quatro dimensões da igualdade democrática: A igualdade diante da lei; é um pressuposto da ampliação concreta da lei, quer proteja, quer puna. É o que os gregos chamavam de isonomia. (BENEVIDES, 1998, p.141). 
Esse princípio, citado pela autora, é colocado como condição sine qua nom, para a cidadania, pois sem a igualdade de oportunidade perante a lei não seria possível pensar em começar a rever conceitos e comportamentos sócio-culturais impregnados na sociedade por uma histórica construção social, em que as mulheres tiveram seus direitos cerceados individual e coletivamente.

A organização internacional elabora a Declaração Universal dos Direitos Humanos em 1948, a partir da Carta das Nações Unidas de 1945. Logo após a Segunda Guerra Mundial, sendo, considerada um marco para a consolidação dos Direitos Humanos. Em seu artigo primeiro estabelece que um dos propósitos das Nações Unidas é alcançar a cooperação internacional para a solução de problemas econômicos, sociais, culturais ou de caráter humanitário e encorajar o respeito aos direitos humanos e as liberdades fundamentais para todos, sem distinção de raça, sexo, língua ou religião.

Outro importante marco jurídico de abrangência mundial é a Convenção para a eliminação de todas as formas de discriminação, artigo $10^{\circ}$ estabelece que devem ser tomadas todas as medidas para implementar programas de educação mista, garantindo direitos iguais as mulheres e promovendo revisão nos textos didáticos preconceituosos e na própria metodologia do ensino. Nos dois casos trata-se de estimular iniciativas de educação para a democracia, nos termos aqui defendidos. (BENEVIDES, 1998, p.148).

A assembleia geral da ONU em uma atitude revolucionária aprova em 1979 a convenção da mulher (Benevides, 1998, p.148) e convida os países membros a se comprometerem com um novo modelo social, combatendo todas as formas de discriminação com o sexo feminino.

É mister, que o congresso nacional só veio a ratificar em 1984, ainda assim com reservas que só em 1994, foram suspensas pelo Decreto 
Legislativo $\mathrm{n}^{0} 26$ (CFEMEA, 2006, p.36) ${ }^{7}$. A partir da Convenção da Mulher, os caminhos foram abertos, novas convenções e tratados internacionais surgem para potencializar a teoria de que mudanças sociais estavam sendo geridas. $O$ Brasil vem assinado os tratados internacionais. Entre eles, destacam-se:

\begin{abstract}
Inicialmente a Convenção Interamericana, para prevenir, punir e erradicar a violência contra a mulher, realizada em 1994 e aprovada pela Assembléia Geral da Organização dos Estados Americanos OEA, com o objetivo de chamar a atenção para as várias formas de violência vivenciadas pelas mulheres no mundo. Ela foi ratificada pelo Brasil em 1995 (CFEMEA, 2006, p.37), provocando um debate acerca da ausência dos Estados nas relações de Gênero e na violência contra o sexo feminino. Seguida da II Conferência Mundial de Direitos Humanos em 1993 na cidade de Viena, onde os direitos das mulheres e das crianças do sexo feminino passam a ser parte inalienável, integral e indivisível dos direitos humanos universais. Onde a participação plena e igual das mulheres na vida política, civil, econômica, social e cultural, a nível nacional, regional e internacional, e a erradicação de todas as formas de discriminação com base no sexo constituem objetivos prioritários da comunidade internacional. (CFEMEA, 2006, p.36).
\end{abstract}

Logo após, realizou se a IV Conferência Mundial sobre a Mulher na cidade de Beijing no ano de 1995. Retratando a Igualdade, o Desenvolvimento e a Paz. Consolidando um novo aspecto da luta, em que, além dos direitos, as mulheres ampliam sua pressão para que os compromissos políticos assumidos pelos governos nas conferências internacionais sejam efetivados por meio da implantação de políticas públicas. (CFEMEA, 2006, p.36).

Observa-se que este evento foi o grande marco para a implantação da primeira lei de cotas de mulheres no Brasil. Portanto, os tratados internacionais desempenharam um importante papel na questão de gênero em território brasileiro. Pois, sem a cobrança dos mecanismos de controle mundial como a

7 -CFEMEA-O Centro Feminista de Estudos e Assessoria - CFEMEA - é uma organização não-governamental, sem fins lucrativos. O feminismo, os direitos humanos, a democracia e a igualdade racial são seus marcos políticos e teóricos. 
ONU seria muito demorado as adequações da legislação nacional. Esta teoria se confirma com a nova Constituição Federal, conforme estudo publicado pelo Centro Feminista de Estudos e Assessoria - CFEMEA:

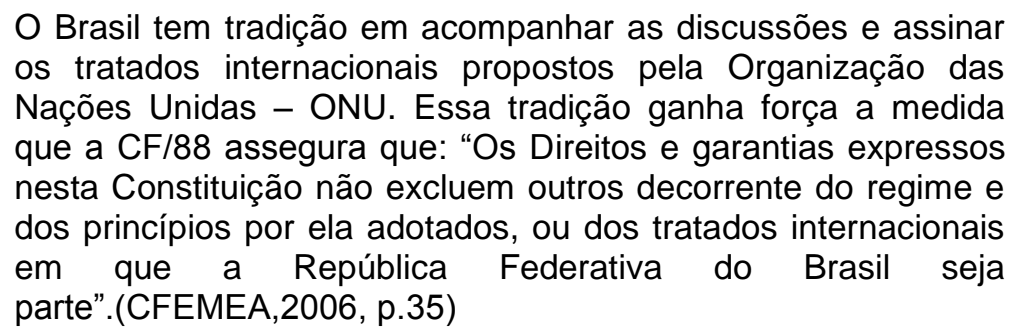

Portanto, existiu uma grande influência dos acordos internacionais sobre o comportamento dos legisladores brasileiros, quando se refere às questões de gêneros em particular sobre o debate das cotas de gênero na eleição.

\subsubsection{Constituição Federal de 1988}

A Carta Magna também trouxe inovações significativas para a sociedade, quanto ao aspecto da inclusão política, social e econômica da mulher brasileira. Pode-se fazer destaque a vários aspecto entre eles artigo $5^{\circ}$ - CF/88, que traz em seu texto a relação de garantias constitucionais como direito social, o inciso I, refere-se a igualdade entre homens e mulheres tanto em direitos como em obrigações.

Trata-se de uma sociedade que no final do século XX ainda se depara com realidades tão desiguais que chega a ser desumana, esta norma é considerada um grande avanço, pois, até então convivi-se com uma estrutura social e política extremamente "machista", patriarcal, em que predomina o ser homem em detrimento ao ser humano.

Portanto, o movimento feminista, que participa ativamente da elaboração da proposta de lei, e a sociedade em geral comemoram esta conquista, que do ponto de vista legal coloca a mulher em pé de igualdade 
com o homem. Utilizando-se dos princípios da equidade, igualdade e da isonomia. Esse fato vem ao encontro de muitas mudanças sociais alcançadas. Porém, a nova Constituição chamada de "Cidadã" abriu caminhos para grandes aliterações nas leis domésticas do País.

\begin{abstract}
Durante o processo de elaboração da Carta de 1998, a bancada feminina do Congresso Nacional (que se resumia às deputadas, visto não terem sido eleitas senadoras), em parceria com o CNDM e os movimentos feministas, conseguiu garantir uma série de direitos apresentados pelas mulheres na "Carta aos Constituintes", documento que continha as principais reivindicações feministas. Atuando de maneira suprapartidária e por meio do que ficou conhecido como "lobby do batom", venceram resistências e preconceitos e conseguiram incluir na Constituição Federal artigos como o $5^{\circ}$, que garante o seu inciso I, que "homens e mulheres são iguais em direitos e obrigações". (PINHEIRO, 2007, p.70).
\end{abstract}

\title{
2.3.3. Código Civil de 2002
}

Após as mudanças trazidas pela nova Constituição Brasileira de 1988, sob o aspecto de gênero, o Código Civil de 1916 até então em vigor, fica sem eficácia, já que "consagra a superioridade do homem, dando o comando único da família ao marido e delegando a mulher casada à incapacidade jurídica relativa" (CABRAL, 2004, p.40).

Diante do novo contexto social, cabe aos Legisladores adequá-lo. Foram intensificados os trabalhos no Congresso Nacional e aprovado a Lei N. 10.406, de 10 de janeiro de 2002, o Novo Código Civil, que foi garantido as adequações das previsões Constitucionais. Com o recorte de gênero. A Capacidade Jurídica foi o grande marco das mudanças que se seguiram.

Destacando-se algumas, entre elas; o Poder Familiar, pois no Código anterior de 1916, a autoridade sob a família era de total responsabilidade do homem, sendo usada a expressão "Pátrio Poder" ou "Poder do Pai". Passando agora a dividir com a mulher essa autoridade com a nova expressão "Poder Familiar". 
A guarda dos filhos em caso de separação, sendo, que no anterior de 1916 o cuidado com os filhos era, em regra obrigação da mãe, agora dividise a responsabilidade e propõe um acordo, considerando as condições de ambos.

Outra novidade trazida foi o conceito de Família, em que constitui uma nova concepção jurídica na composição familiar, passando a ser considerada mãe e filho como um núcleo familiar; E por último o Direito a Alimentos que até então era prerrogativa da mulher casada, com a nova legislação, é direito da companheira ou mãe solteira também.

\subsection{Lei de Cotas de Gênero}

\subsubsection{Cotas de gênero}

As mudanças na legislação e no comportamento social, além das cobranças internacionais, convida a Sociedade Brasileira a colocar na agenda um debate sobre a implementação de uma Política Publica, chamada de "Ações Afirmativas", que conforme relata Marlise Matos (MATOS, et al 2007, p.2) para o Movimento Feminista, visa diminuir a desigualdade entre os dois sexos.

Destaca-se uma ação compensatória que contribuirá no processo de inclusão delas que foram por um longo período cerceadas de seus direitos de participação ativa nos espaços de decisão. As cotas poderiam ser segundo Araújo (2001, p.3) de dois tipos, uma seria a reserva do numero de candidatos registrados pelos Partidos Políticos e a outra seria a reserva do numero de assentos nos Parlamentos.

Cabe-se, ainda, perceber o contexto em que o Congresso Nacional Brasileiro propõe, analisa e aprova a legislação que regulamenta esta prerrogativa legal. Araújo (2001) discorre, em seu texto: "As Cotas por Sexo para a Competição Legislativa; O Caso Brasileiro em Comparação com Experiências internacionais", sobre esta divisão: 
Existem dois tipos de cotas voltadas para as mulheres: as aplicadas pela legislação e as adotadas por iniciativa voluntária dos partidos políticos. Em relação às primeiras, encontram-se aquelas que incidem sobre o processo eleitoral, isto é, sobre as listas que os partidos irão apresentar para concorrer ${ }^{3 / 4}$ um percentual mínimo de reserva das vagas dos concorrentes paras as mulheres ou para cada sexo ou, ainda, através da paridade, como na legislação francesa recentemente aprovada, e existem as cotas que se aplicam diretamente ao parlamento, via a reserva de assentos a serem ocupados pelas mulheres. (ARAÚJO, 2001, p.3).

Essa ideia de criação de um instrumento legal que obrigasse as Nações a ceder espaço às mulheres foi se fortalecendo com a estruturação de novos modelos sociais, entre eles a tão sonhada Democracia Brasileira, conquistada com a Carta Magna de 1988. Porém, o desafio continua incluir as minorias historicamente excluídas no campo cultural, econômico, social e acima de tudo político:

\begin{abstract}
Se a democracia é antes de tudo, um sistema político com caráter inclusivo, pode-se perguntar qual é a sua legitimidade quando exclui metade da população das possibilidades de representação, quando ignora suas necessidades e a alija de medidas concretas que possibilitem a melhoria de suas condições de vida. Assim, há uma lógica que confirma as mulheres ao mundo doméstico e as concebe basicamente em sua identidade como mães, e fora de casa como demandantes de ações comunitárias, algumas vezes como beneficiárias das políticas públicas, mas raramente como sujeitos capazes de protagonizar processos políticos. (SOARES, 2004, p.176)
\end{abstract}

Os Legisladores Brasileiros foram motivados a responder questionamentos como esses que os levaram a refletir a partir do modelo econômico, social e político que estava estruturada a sociedade naquele momento. Qual seria o papel do Estado para rever essa situação? Como aproveitar a contribuição trazida pelos mecanismos internacionais de Direitos Humanos?

Borba (1998, p.160) relata qual sua leitura daquele momento histórico de conquista da Lei de Cotas:

A grande novidade das eleições de 1996 foi a introdução, na legislação eleitoral, da obrigatoriedade da cota mínima de $20 \%$ de mulheres nas listas partidárias para as eleições 
proporcionais. Por iniciativa da deputada Marta Suplicy (PTSP), com o apoio de mais de 30 deputados, em agosto de 1995 foi apresentado projeto de lei propondo a cota mínima de $30 \%$ de mulheres nas listas para as eleições parlamentares em todos os níveis. Marta, apoiada nas experiências de paises europeus e da Argentina - e no PT, que em 1991 estabelecera cota mínima de $30 \%$ de mulheres nos órgãos de direção partidária - , estava convencida de que só com políticas de ação afirmativa se poderia alterar o quadro de representação feminina nas casas legislativas. O projeto ainda não havia sido apreciado quando se depararam as regras para as eleições de 1996. Marta apresentou junto com o deputado Paulo Bernardo (PT-PR), emenda com o mesmo teor à proposta de Lei Eleitoral. A proposta foi acolhida pelo relator da matéria, mas com redução de $30 \%$ para $20 \%$ e com o aumento de $100 \%$ para $120 \%$ do número de candidatos, o que na pratica representou uma cota de $16,66 \%$.

Essa ação, iniciada pela deputada Marta Suplicy, motivada por experiência internacionais e partidárias, somada ao apoio de grupos de Mulheres, segundo Borba (1998, p.160) foi apresentado em 1995.

De fato, a primeira proposta da chamada Lei de Cotas de Gênero, sancionada com o n. 9.100/1995, veio estabelecer que o percentual de $20 \%$ das vagas na lista de registro eleitoral fossem reservadas as mulheres para as próximas eleições municipais de 1996. Em seguida, a proposta foi alterada para $30 \%$ das vagas e muda a expressão de "MULHERES "para "SEXO", Lei n. 9.504/97. O que na prática deixa de ser uma reserva exclusiva às mulheres e passa a ser para qualquer um dos sexos que estiver em minoria, ou seja, a exigência é de que não poderá registrar mais de $70 \%$ de candidaturas do mesmo sexo. Outra adequação e de que a prerrogativa foi contemplada na legislação eleitoral, passando a regular todos os processos eleitorais.

\section{Lei n. 9.100/95:}

Art. 11.

$\S 3^{\circ}$ Vinte por cento, no mínimo, das vagas de cada partido ou coligação deverão ser preenchidas por candidaturas de mulheres.

Lei n. 9.504/97 
Anterior:

Art. 10

$\S 3^{\circ}$ Do número de vagas resultante das regras previstas neste artigo, cada partido ou coligação deverá reservar o mínimo de trinta por cento e o máximo de setenta por cento para candidaturas de cada sexo.

Atual:

$\S 3^{\circ}$ Do número de vagas resultante das regras previstas neste artigo, cada partido ou coligação preencherá o mínimo de 30\% (trinta por cento) e o máximo de $70 \%$ (setenta por cento) para candidaturas de cada sexo.

É mister, destacar como a maioria dos deputados eram homens,estes aprovaram a lei, porém, paralela a ela, votou-se também o aumento das vagas na lista dos partidos, sendo num primeiro momento um aumento de $20 \%$ e logo depois $50 \%$.

Com isso, o que parece coincidência pode ser uma condição imposta, de maneira que mesmo abrindo para a possibilidade de ter o aumento de mulheres candidatas não poderia abrir mão das vagas masculinas. Conforme relatos acorridos na época e registrados por várias pesquisadoras. Entre elas, Clara Araújo, sendo:

Ao mesmo tempo, o numero de vagas na lista eleitoral foi ampliado, passando de $100 \%$ para $120 \%$ do total de cadeiras em disputa. Completar o mínimo de $20 \%$, porém, não foi definido como algo obrigatório na legislação, já que os partidos não poderiam preencher 0 percentual mínimo com nomes masculinos, mas poderiam deixá-lo em aberto caso não houvesse mulheres suficientes para fazê-lo. No final de 1997, quando foi votada a nova lei eleitoral, de $n^{\circ} 9.504$, que estabeleceu regras permanentes para os futuros pleitos eleitorais, a reserva de vagas na forma de cotas foi incluída como legislação permanente. Ficou definido que nas eleições parlamentares de $1998^{3 / 4}$ para deputados federais ${ }^{3 / 4}$ as cotas seriam, transitoriamente, de $25 \%$ como o mínimo a ser preenchido por cada sexo. A partir daí, nas eleições seguintes, o percentual mínimo deveria ser de $30 \%$. Também nesse caso, ampliou-se o numero de vagas nas listas eleitorais, passando a um máximo de $150 \%$ das cadeiras em disputa. O preenchimento das cotas permaneceu orientado pela norma aprovada em 1996, isto é, os partidos seriam obrigados a manter o percentual de reserva e não poderiam ocupar as vagas com candidatos do outro sexo, mas não seriam obrigados a preenchê-las integralmente com candidatos do mesmo sexo. (ARAÚJO, 2001, p.7). 
Alguns anos depois do advento da Lei n. 9.504/97, foi introduzido outra alteração com a Lei n.12.034/2009 agora a nova redação passa a vigorar com a expressão: "preencherá o número de vagas", o que obriga agora a ocupação do espaço das mulheres na lista, portanto, o que antes era só uma prerrogativa, passa a ser uma condição para o registro de suas candidaturas.

Ainda, que cada partido é obrigado a investir $5 \%$ dos recursos do seu fundo partidário, as organizações de mulheres de cada partido, bem como, o tempo de $10 \%$ nos horários de propaganda de cada partido. Essa norma visa fortalecer a possibilidade real da presença feminina nos espaços de poder, Lei n.12.034/09:

Art. 44 -V - na criação e manutenção de programas de promoção e difusão da participação política das mulheres conforme percentual que será fixado pelo órgão nacional de direção partidária, observado o mínimo de 5\% (cinco por cento) do total.

Art. 45

IV - promover e difundir a participação política feminina, dedicando às mulheres o tempo que será fixado pelo órgão nacional de direção partidária, observado o mínimo de $10 \%$ (dez por cento).

Art. 10

§ 30 Do número de vagas resultante das regras previstas neste artigo, cada partido ou coligação preencherá o mínimo de $30 \%$ (trinta por cento) e o máximo de $70 \%$ (setenta por cento) para candidaturas de cada sexo.

É importante analisar alguns números que retratam a presença feminina nas Câmaras de Vereadores, nas Assembleias Legislativas Brasileiras, o número de votos destinados às mulheres. Comparando os anos anteriores e posteriores à implantação da nova legislação eleitoral que introduz a prerrogativa de cada partido político registrar um número mínimo de candidatos de cada sexo. 
Tabela 4 - Evolução das Vereadoras Eleitas Brasil, 1992, 1996 e 2000

\begin{tabular}{|c|c|c|c|}
\hline & 1992 & 1996 & 2000 \\
\hline $\begin{array}{c}\text { Total de } \\
\text { eleitos }\end{array}$ & $\begin{array}{l}53.962 \\
(100 \%)\end{array}$ & $\begin{array}{l}58.324 \\
(100 \%)\end{array}$ & $\begin{array}{l}60.267 \\
(100 \%)\end{array}$ \\
\hline $\begin{array}{c}\text { Do sexo } \\
\text { feminino }\end{array}$ & $3.952(7,5 \%)$ & $6.536(11,2 \%)$ & $7.001(11,6 \%)$ \\
\hline
\end{tabular}

Fonte: IBAM (1997) e TSE (1996; 2000). (ARAÚJO, 2001, p.9)

Tabela 5 - Evolução da Participação das Mulheres nas Assembleias Legislativas Brasil, 1982-1998

\begin{tabular}{|l|l|l|l|l|}
\hline Ano & $\begin{array}{l}\text { Total de } \\
\text { eleitos }\end{array}$ & $\begin{array}{l}\text { Mulheres } \\
\text { eleitas }\end{array}$ & $\begin{array}{l}\text { \% do } \\
\text { total }\end{array}$ & $\begin{array}{l}\text { Incremento } \\
(\%)\end{array}$ \\
\hline 1982 & 947 & 28 & 3,0 & - \\
\hline 1986 & 953 & 31 & 3,3 & 10,7 \\
\hline 1990 & 1049 & 58 & 5,5 & 87,0 \\
\hline 1994 & 1045 & 82 & 7,8 & 45,5 \\
\hline 1998 & 1036 & 101 & 9,7 & 23,2 \\
\hline
\end{tabular}

Fontes: TSE (1996; 2000); Nicolau (1998); Avelar (1996). (In: ARAÚJO, 2001, p.10). 
Após análise, pode-se perceber que historicamente existe uma pequena presença feminina no legislativo brasileiro. Contudo nota-se a pouca evolução a partir de 1996, sendo que as vereadoras obtêm em 1992, 7,5\% do total de votos e em 1996, 11,2\% (Ver em tabela 4 Evolução das Vereadoras Eleitas Brasil, 1992, 1996 e 2000).

Enquanto as Deputadas Estaduais obtém em 1994, 7,8\% e 9,7\% em 1998 (Ver em tabela 5 - Evolução da Participação das Mulheres nas Assembleias Legislativas Brasil, 1982-1998). Esses dados mantêm a media de crescimento que elas haviam desempenhado nas eleições anteriores. Portanto um impacto pouco significante quanto ao resultado final e menor ainda quando mensurado a expectativa do movimento de mulheres. Vale registrar que os poucos presentes nos espaços se demonstravam muito articuladas e estimuladas, tornado mais visível a presença das mesmas nos espaços de poder.

\footnotetext{
Cabe lembrar que os objetivos das cotas foram definidos em dois níveis: um primeiro, mais concreto, que seria o de ampliar a presença de mulheres na representação política, como candidatas, mas sobretudo, como eleitas, e um segundo, definido como mais simbólico, visando alterar a cultura política, marcada por percepções de gênero que naturaliza as desigualdades. (ARAÚJO, 2001, p.8).
}

Porém, cabe a grande pergunta, será que estes objetivos foram alcançados? Aumentaram os assentos ocupados por mulheres? Houve mudanças efetivas no comportamento social?

\section{Conclusões Finais}

As mudanças no comportamento social e na legislação, além das cobranças dos Tratados Internacionais, convida a Sociedade Brasileira a 
colocar na agenda um debate sobre a implementação de Políticas Públicas, visando diminuir a desigualdade entre os dois sexos.

Tornam-se imperiosas as ações compensatórias que contribuam no processo de inclusão delas, as quais foram, por um longo período, cerceadas de seus direitos de participação ativa nos espaços de decisão.

O Brasil optou pela Cota da Lista Eleitoral, na tentativa de reverter suas estatísticas que eram negativas para sua Democracia. Esta pesquisa aprofunda nos dados, para verificar o resultado, desde a posição em nível mundial até a realidade do Congresso Nacional, o número 8,2\% de Deputadas Federais no ano de 2010, e de 91,8\% de Deputados Federais, confirma a distancia existente entre a previsão legal de $30 \%$ de reserva de gênero e a realidade social, econômica, cultural e política nacional.

A partir dessas condições, percebe-se que mesmo com a maturidade da lei, não se alcançará a médio e longo prazo a mudança desejáveis nas estatísticas.

Porém, esta pesquisa criou a oportunidade de afirmar que no mínimo as cotas conseguiram aguçar a participação feminina e com isso Estado tende a criar condições mais favoráveis à ampliação do número de mulheres nos espaços de Direção, seja Público ou Privado.

Portanto, a mera existência da previsão legal não garante a mulher real acesso ao poder. As Cotas não irão mudar as relações de poder, uma vez que ela não representa um elemento que modifica a composição dos órgãos diretivos, e sim a composiçao somente do número de candidatas. Observa-se que tal lei proporciona a vinda de novas ideias para o debate .

Hoje, portanto, percebe-se que há muito pouco a comemorar. Mesmo considerando os avanços. Os desafios continuam presentes na sociedade. Para mudar essa realidade nacional, será necessário rever o modelo de cota atual, implantando a reserva no assento do legislativo e novas Políticas Públicas, de inclusão social do sexo feminino. 


\section{REFERÊNCIAS}

ARAÚJO, C. As cotas por Sexo para a competição legislativa: o caso brasileiro em comparação com experiências internacionais. Rio de Janeiro, v.44, n.1, jan/2001. Disponível em: < http://www.scielo.br> Acesso em: 24 mar. 2011.

BENEVIDES, Maria Victoria de Mesquita. 1992. A cidadania ativa. São Paulo, Ática, 1998.

BORBA, A. et al. Mulher e Política: gênero e feminismo no Partido dos Trabalhadores. 1 ed. SP: Fundação Perseu Abramo, 1998.

CABRAL, Karina Melissa. Direito da Mulher de acordo com o Novo Código Civil. Editora de Direito, 2004.

CFEMEA. Os direitos das mulheres na legislação brasileira pósconstituinte - Legislação (Federal, Estadual e Municipal) sobre direitos das mulheres a partir da constituição de 1988. Brasília: Letras Livres, 2006.

DELGADO. Maria Berenice Godinho. Mulher e Política: Gênero e feminismo no Partido dos Trabalhadores. São Paulo: Editora Fundação Perseu Abramo, 1998.

FERREIRA, M. Mulher e Política: Do voto feminino à Lei das Cotas: a difícil inserção das mulheres nas democracias representativas. Disponível em: <www.espaçoacademico.com.br/036/37cferreira.htm> Acesso em: 24 mar, 2010.

GARCIA, Ivete. Gênero e políticas públicas municipais. 1998. Disponível em Disponível em http//www2.fpa.org.br/uploads/lvete.pdef. Acesso em 10 de dezembro de 2012.

GODINHO, Tatau. BORBA, Angela (org.) Mulher e Política: Gênero e feminismo no Partido dos Trabalhadores. São Paulo: Editora Fundação Perseu

Abramo, 1998.

Disponível

em 
http//www2.fpa.org.br/uploads/lvete.pdef. Acesso em 10 de dezembro de 2012.

http://www2.fpa.org.br/uploads/ivete.pdf

.. Lei n. 9.100 de 29 de setembro de 1995. Estabelece normas para

a realização das eleições municipais de 3 de outubro de 1996, e dá outras providências. Disponível em: <www.planalto.gov.br> Acesso em 28/03/2011.

. Le n. 9.504 de 30 de setembro de 1997. Estabelece normas para as eleições. Disponível em: <www.planalto.gov.br> Acesso em 28/03/2011

MATOS, Marlise, et al. Cotas de Gênero para o reconhecimento das Mulheres na Política: um estudo comparado ações afirmativas no Brasil, Argentina e Peru. Disponível em: <www.maismulheresnopoderbrasil.com.br> Acesso em: 25 mar. 2011.

MELO, Hildete Pereira. Gênero e Pobreza no Brasil. Relatório Final do Projeto Gonernabilidad Democratica de El Género Em America Latina y El Caribe. Convênio:Comissão Econômica para América Latina e Caribe (CEPAL) Secretaria Especial de Políticas para as Mulheres (SPM),Brasília, 2005.

PAULILO, Maria Ignez Silveira. Mulher e Cidadania. 1999. Disponível em: http://www.ssrevista.uel.br/c_v2n2_mulher.htm. Acesso em 17 de mar.2012.

PINHEIRO, Luana Simões. Vozes Femininas na Política: uma análise sobre mulheres parlamentares no pós-Constituinte. Brasília: Secretaria Especial de Políticas para as Mulheres, 2007.

PINTO, Célia Regina Jardim. Uma história do feminismo no Brasil. São Paulo: Fundação Perseu Abramo, 2003.

RAGO, Margareth. A mulher brasileira nos espaços público e privado. São Paulo: Fundação Perseu Abramo, 2004.

RIBEIRO, Matilde. Antigas personagens, novas cenas:mulheres negras e participação política. Disponível em http://empreende.org.br/pdf/Programas\%20e\%20Pol\%C3\%ADticas\%20Sociais/ Antigas\%20personagens\%20mulheres\%20negras.pdf 
SOARES, Vera. O feminismo e o machismo na percepção das mulheres brasileiras. In: A mulher brasileira nos espaços público e privado. $1^{\circ}$ ed. São Paulo: Editora Fundação Perseu Abramo, 2004, p. 161-180. 